\title{
99 ways to get those feet in the door
}

\author{
How to develop a public relations campaign
}

\author{
by Carol Anne Germain
}

A re "popular" areas of your collection collecting dust? Are faculty surprised when you tell them that you'll do a BI session tailored to their courses? Are students coming into your library after an assignment is clue oblivious to the fact that they needed the library three months ago? Do your statistics show low circulation and/or inadequate door count numbers? Do the library-sponsored Internet/Electronic Database classes only draw only two or three people, even though they're free?

If you're like me, the answer to many of these questions, if not all of them, is yes. To librarians, it seems only logical that students and faculty would find it impossible to not use the college library. Yet, we know that a fair amount of the campus population is not taking advantage of our services and resources.

Do students and faculty avoid the library or are they unaware of the treasures we have? Do we take for granted that since we realize that the library is the heart of the campus that everyone else does too? Developing a public relations campaign may help get students and faculty into the library.

\section{Get the word out to get 'em in}

One of the key components of a successful public relations campaign is communication.
Academic libraries need to communicate to the campus community what they are and all they have to offer. Getting the word out will get the patrons in. You can't tell enough people about your library-from the college president to the secretary of the math department.

\section{Form a committee}

If your library is interested in initiating a public relations campaign, a good start is to organize a committee devoted to this objective. This group should consist of individuals who are passionate about the library's services and resources. They should also have the ability to communicate that passion. Try to include individuals from outside the library, such as students, faculty and/or campus administrators; the insight they provide will be amazing!

The charge of this committee should be to analyze the library needs of the campus, to define strategies that address these needs, to implement an outreach program, and to evaluate the results. One library staff member should be designated as public relations coordinator. This person will take responsibility for the administrative work, including setting up meetings, surveys, etc. Release time or other compensations should be established with this person to avoid work overload.

\section{About the author}

Carol Anne Germain is networked resources education librarian at the University of Albany; e-mail: cg219@cnsvax.albany.edu 
Having a frazzled promoter is a ticket for disaster.

Promoting your library is important, but prior to exerting any public relations energy, an internal review of the library's public service points is necessary. The greatest and most creative outreach efforts are worthless if you get students, staff, and faculty into an unpleasant setting. Before you begin advertising your library and services, set up a program within the library encouraging all staff to be friendly and helpful with patrons.

Superior customer service means a good image for the library. Students and faculty who have good experiences at the library will encourage others to use it. A positive attitude is often contagious; be the spark! Encourage all library employees to take part in the outreach process: ask for ideas, let them know about what's going on, ask for feedback, persuade them to take your BI classes, make everyone a part of the process.

\section{Get to know your campus}

The next step is to find out about your campus. You will be surprised to find you know as little about the rest of the campus as they know about the library! Make phone calls, go to offices, and attend staff meetings. Personal contact contributes more to the success of an outreach effort than organizational skills or funding.

Find out about freshmen-year programs and services for minority and disabled students. Touch base with residence hall staff and research every academic department from athletics to zoology. Reach out to faculty. They play a central role on college and university campuses, and their perception of library service may be a key factor in the way the campus library is used and supported. If your college has something unique, such as the National Weather Service located on campus, get details about it and suggest a collaborative project.

Ask questions, toss out ideas, ask for feedback, and, most importantly, listen-you're connecting with your audience. Many of the people you contact will have ideas that will make your outreach a success. If you know your audience's wants and needs, you have a better chance of reaching them.

While you may not be able to offer them a coffee bar, you may draw them in with an open-mike poetry reading. Conduct focus groups, interviews, and/or surveys before developing your public relations strategy. Try to conduct these outside the library so that you'll be asking questions to the people you want to bring into the library.

Once you've collected this data, you will find that the campus is not a one-size-fits-all audience. There will be many target groups that have different needs and modes of approach. A sorority may be thrilled with an all-night romance movie sleepover in the library, but this won't work with the football team.

\section{Preparing your PR plan}

Questions to ask when preparing the public relations plan should include:

- What are the needs and wants of your target group?

- What library-related resources are they interested in?

- What mode(s) of advertisement will lure them into the library?

- Are there particular areas you would like to focus on, such as increasing video circulation or promoting new integrated workstations?

It is important to establish attainable goals. You may not be able to get every person on campus into the library, but you may be able to inform members of specific groups. Make a list of goals for the short term and a wish list for the future. Try to make your public relations efforts exciting and different.

Posters advertising your BI sessions work for some people, but often there's so much to read on campus that they're overlooked. Try using a couple of the 99 suggestions that follow or think of new ones that will benefit your campus. Maintain contacts with faculty, staff, and others who helped along the way. Send an e-mail, phone, and/or write a thank you card: communication, communication, communication!

Finally, you will need to evaluate your program. Are more students coming to the reference desk for help? Is your suggestion/ comment box fat with positive remarks? Are more of the faces on campus becoming familiar faces? Are your statistics increasing?

If your plan is working, you will see results. You will need to pull out the public relations plan every few months to re-evalu- 
ate what you've done and decide what to continue and what new strategies you'd like to implement. Be careful, though, you may get what you wish for!

\section{The 99 ways}

1. Smile when you see students outside the library.

2. Work with the student newspaper (try for a regular column).

3. Provide exhibit space for student organizations.

4. Set up a table in the student union at the beginning of each semester; let students know what's available, including videos, books of interest, computer resources, etc.

5. Design graduate school/transfer BI sessions.

6. Eat lunch with students.

7. Attend student association meetings.

8. Develop a Web page specifically for remote users and distance learning students.

9. Have a liaison on the faculty senate.

10. Sponsor an alternative rock/poetry festival.

11. Use campus (including dorms) bulletin boards to promote the library, library services or new books, videos, etc.

12. Support the writing center by providing guides, handouts, BI class schedules, etc., and provide workshops to staffers.

13. Have a link from the main page of your institution to the library's Web page.

14. Reach out to resident assistants; they get more questions about the library than we do!

15. Co-sponsor events with student organizations.

16. Give away small items, e.g., balloons, pencils, pens, etc., with the library logo.

17. Post notices to campus LISTs and newsgroups promoting new databases, classes, exhibits, etc.

18. Hold lectures of interest: campus food, safety, diversity.

19. Let students know that classes are free.

20. Give students and faculty your business card.

21. Advertise in the student newspaper and organization/department newsletters.

22. Develop handouts for special populations (students with disabilities, students in need of academic support, etc.).

23. Set up a booth at campus job fairs.
24. Be a guest speaker at residence hall meetings.

25. Sponsor a costume contest: literary characters, science fiction personalities, "create your own."

26. Have a student/faculty art section.

27. Own the most comfortable chairs on campus.

28. Organize a Halloween, original storytelling hour.

29. Make the library inviting with flowers, plants, balloons, etc.

30. Represent the library at the campus open house sessions.

31. Use campus mail and send enticing notices for classes.

32. Post Internet/database class schedules in user rooms.

33. Produce library survival kits for faculty/advisors.

34. Send out postcards welcoming students.

35. Make sure there's a library catalog icon on student/user room desktops.

36. Present a workshop for new faculty orientation.

37. Have a banner in the campus center.

38. Sponsor a book-signing session for faculty.

39. Inform campus tour guides of "fun" resources in the library.

40. Co-teach with academic computing.

41. Let sponsored study groups know about library resources.

42. Post classes on the institution calendar.

43. Start up a student peer help group.

44. Sponsor an ethnic food festival.

45. Assemble a packet for distribution at student orientation.

46. Have handout racks with appropriate study guides in the campus center, dorms, and academic offices.

47. Hang up eye-appealing notices for upcoming classes.

48. Let the health center and counseling groups know about library resources, students often complain to these people about research stress.

49. Solicit and distribute promotional materials from database vendors.

50. Create a library newsletter.

51. Reach out to department secretaries; they see students more often than their advisors do! 
52. Invite the campus mascot to the library.

53. Sponsor hall-by-hall milk and cookies sessions.

54. Have regular office hours.

55. Design table tents that advertise the library's Web page on meal tables.

56. Conduct surveys, focus groups, and interviews to find out what students want from the library.

57. Co-sponsor workshops with the career development center.

58. Underwrite an ice cream social.

59. Meet personally with faculty members and deans to let them know what's available to them and their students.

60. Make sure that the library is listed in campus promotional materials.

61. Initiate and maintain a current events bulletin in the library.

62. Work in conjunction with local high schools to let them know what your library has; these may be future students.

63. Have library handouts and BI class schedules available at the registrar's office.

64. Provide tours and instruction sessions for TAs and GAs.

65. Ask the bookstore to carry BI class schedules.

66. Have search sessions tailored to fraternities/sororities.

67. Create recommended reading bookmarks, tailored to specific classes, and have professors distribute them.

68. Work with academic computing and other campus departments to co-sponsor a technology fair.

69. Contact the athletics department and let them know about library services and the possibility of a sports BI session.

70. Involve students in the development of your Web pages.

71. Coordinate with your performing arts center, art gallery, and/or museum to have exhibits that overlap with their specific productions/art exhibits.

72. Develop a pre-midterm survival pack.

73. Include a fun page on your library's Web page.

74. Visit the dorm and campus user rooms.

75. Be a sponsor or drop off station for aid programs, such as Toys for Tots.

76. Work with the music department to have a music series throughout the year.

77. Advertise on the school buses.
78. Support the yearbook.

79. Participate in one of the school trips.

80. Let financial aid know about your free BI sessions.

81. Have a library resources card to be distributed with the campus card.

82. Teach a scholarship/financial aid BI session.

83. Have BI classes posted in the college bulletin.

84. Ensure that the library is a safe place, even at night.

85. Co-sponsor a stress-free research session with the counseling center.

86. Work with resident assistants on their floor bulletin board.

87. Develop a special handout, outlining services, to be sent to students enrolled in distance learning courses.

88. Send out summer BI schedules to all summer session professors.

89. Develop an information literacy course.

90. Advertise in the sports center with a banner or sponsor sports tickets for a semester.

91. Be a faculty mentor.

92. Air announcements on the campus radio and/or TV station.

93. Provide remote site $\mathrm{BI}$ for distance learners.

94. Work with professors and TAs to develop appropriate assignments for students.

95. Schedule student tours and BI sessions for pre-college programs, such as the summer bridge.

96. Send flyers to all student organizations.

97. Be a distribution point for student newspapers/newsletters.

98. If your college has an information unit, give them information.

99. Encourage service point employees to have positive attitudes. If your library is a place that people dread, all the outreach in the world is useless!

\section{Notes}

1. Donald Dilmore, "Librarian/Faculty Interaction at Nine New England Colleges," College \& Research Libraries 57 (May 1996): 274-84.

2. Lynn Westbrook and Robert Waldman, "Outreach in Academic Libraries: Principle into Practice," Research Strategies 11 (Spring 1993): 60-5. 

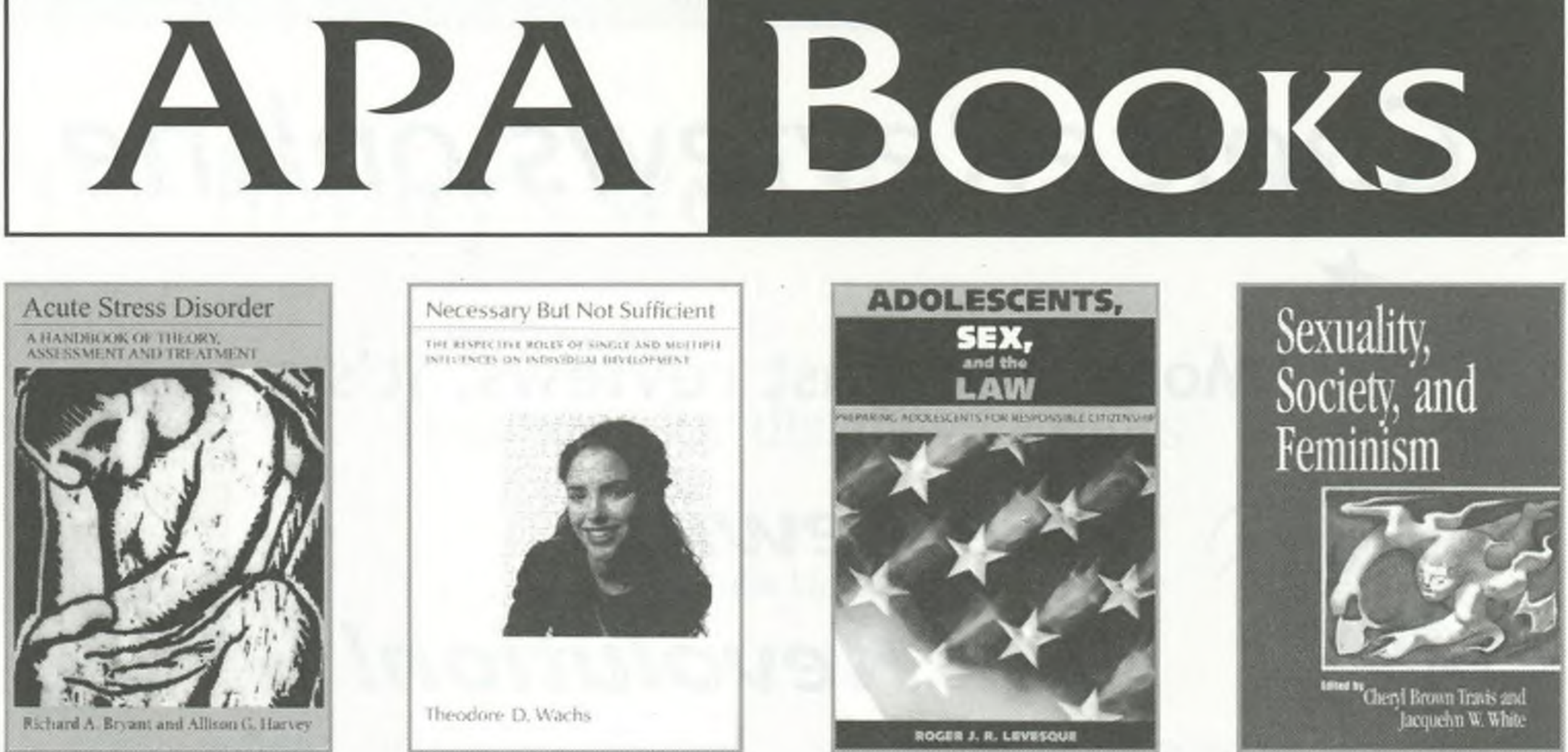

Adolescents, Sex, and the Law: Preparing Adolescents for Responsible Citizenship

Roger J.R. Levesque | 1999 | About 248 pages | Hardcover

APA Member/Affiliate: $\$ 34.95$; List: $\$ 39.95$ | Item \# 431626A | ISBN: 1-55798-609-6

Necessary But Not Sufficient:

The Respective Roles of Single and Multiple Influences on Individual Development

Theodore D. Wachs | $1999 \mid 480$ pages | Hardcover

APA Member/Affiliate: \$39.95; List: $\$ 49.95$ | Item \# 4318890 | ISBN: 1-55798-611-8

\section{Sexuality, Society, and Feminism}

Edited by Cheryl Brown Travis and Jacquelyn W. White| 1999 | About 440 pages | Hardcover Part of the Psychology of Women book series, a collaborative effort between APA's division of the Psychology of Women and APA books.

APA Member/Affiliate: \$39.95; List: \$49.95 | Item \# 431628A | ISBN: 1-55798-617-7

Reconciling Empirical Knowledge and Clinical Experience:

The Art and Science of Psychotherapy

Edited by Stephen Soldz and Leigh McCullough | 1999 | About 300 pages | Hardcover APA Member/Affiliate: \$34.95; List: \$39.95 | Item \# 431734A | ISBN: 1-55798-603-7

Acute Stress Disorder: A Handbook of Theory, Assessment, and Treatment

Richard A. Bryant and Allison G. Harvey| 1999 | About 240 pases | Hardcover APA Member/Affiliate: \$34.95; List: \$39.95 | Item \# 431737A | ISBN 1-55798-612-6

Handbook of Psychotherapy with Lesbian, Gay and Bisexual Clients Edited by Ruperto M. Perez, Kurt A. DeBord, and Kathleen J. Bieschke | 1999 | About 464 pages | Hardcover APA Member/Affiliate: \$39.95; List: \$49.95 | Item \# 431736A | ISBN: 1-55798-610-X

\section{Practicing Feminist Ethics in Psychology}

Edited by Mary M. Brabeck | 1999 | About 272 pases | Part of the Psychology of Women book series, a collaborative effort between APA's division of the Psychology of Women and APA books.

Hardcover: APA Member/Affiliate: \$34.95; List: \$39.95 | Item \# 4312300 | ISBN 1-55798-623-1

Softcover: APA Member/Affiliate \& List: \$29.95 | Item \# 4312301 | ISBN 1-55798-635-5

The Hidden Prejudice: Mental Disability on Trial

Michael L. Perlin| 1999 | About 400 pages | Hardcover

APA Member/Affiliate: \$39.95; List: \$49.95 | Item \# 431627A | ISBN: 1-55798-616-9

\section{www.apa.org/books 1-800-374-2721}




\section{ChoiceReviews.online $\star$}

More than just reviews, it's a

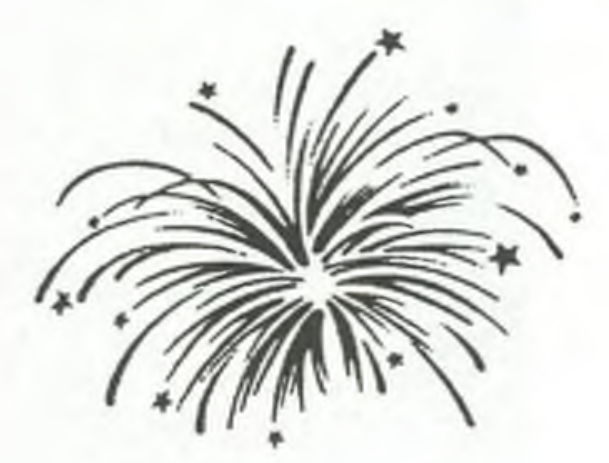

\section{Reviewing \\ Revolution!}

*

$\star$ Access to nearly 70,000 reviews via the Internet

$\star$ E-mail notification of new reviews, based on individual subject interests

$\star$ Searchable database includes all CHOICE reviews * since September 1988

$\star$ Customized list creation, storage, and management

$\star$ Password access allows high degree of customized use

$\star$ SUBSCRIBE NOW for $\$ 395$ !

\section{It's more than just a * database of reviews $\star$

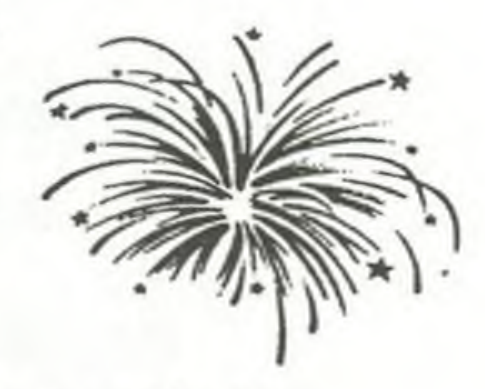

Basic annual subscription includes all corresponding print issues of the magazine and up to 20 passwords. Current magazine subscribers can receive credit adjustments for conversion to the ChoiceReviews.online service.

Call now for details! $*$

Phone: (860)347-6933 x33 Fax: (860) 704-0465

E-mail: subscriptions@ala-choice.org

www. ChoiceReviews.org

100 Riverview Center, Middletown, CT 06457 * 